\title{
PAPILLOMA CHOROIDEUM WITH DIFFUSE GENTRAL NERVOUS SYSTEM METASTASES
}

\author{
BY
}

\section{GEORGE W. HALL aNd THOMAS L. FENTRESS, Chicago}

Papilloma choroideum is one of the relatively uncommon intracranial tumours. Davis and Cushing ${ }^{1}$ in 1925 reported six cases out of a series of 964, or 0.6 per cent. In 1930, Van Wagenen ${ }^{2}$ made an exhaustive review of the literature, in which he found only 45 cases, and added two of his own. Since then, four new cases have been reported, two by Vincent ${ }^{3}$ and one each by Spota ${ }^{4}$ and Guillain. ${ }^{5}$

Although this tumour is typically localized, Van Wagenen studied the question of seeding and found that in six cases this had occurred. The first case of the kind was reported in 1868 by Le Blanc. ${ }^{6}$ His case was a papilloma of the left lateral ventricle which metastasized to the right parietal region. Additional examples of seeding were reported by Bielschowsky and Unger ${ }^{7}$ in 1902, Van Bouwdijk ${ }^{8}$ in 1914, Toppisch ${ }^{9}$ in 1925, and Gromelski ${ }^{10}$ in 1926. The second case of Van Wagenen was also an example of seeding, in that a papilloma of the left lateral ventricle was found to have spread to the third and right lateral ventricles.

The case which we are reporting is of interest both because of the rarity of this type of tumour, and because of the clinical difficulties which were present.

\section{REPORT OF A GASE}

History.-J. R., a white male, age 61, was admitted to the service of the senior author at St. Luke's Hospital on January 3, 1932. He gave a history of having begun to feel 'run down' about a year previously. This had become progressively worse, and in the course of a year he had lost $30 \mathrm{lb}$. Eight months before admission he had girdle pains around his waist associated with mild nausea. Two months later he developed an intermittent, right sciatic pain which after three months became bilateral. There had been some vague urinary symptoms for which a prostatectomy had been done four months before admission. The past history was unimportant, except for a Neisserian infection as a young man, and a penile sore in 1898 . He stated that he had never received any antiluetic treatment, and that a blood Wassermann had been negative on several occasions.

Examination.-The general examination was negative except for marked emaciation, a blood pressure of $150 / 104$, and the recent prostatectomy scar. Neurological examination revealed that the right pupil was slightly larger than the left, but both pupils reacted normally to light and on accommodation. The ocular fundi were normal, except for slight arteriosclerotic changes. There was a right sixth nerve paresis with diplopia which was said to have been present for years. The cranial 
nerves were otherwise normal. A generalized weakness of the musculature was observed without any localized atrophy or fibrillary twitchings. The tendon reflexes of the upper extremities were normal, as were the abdominal reflexes. The knee-jerks could not be obtained except by reinforcement, and the Achilles-jerks were both absent. There was a negative Hoffman and Babinski sign on both sides. There was no ataxia. The vibratory sense at both ankles was moderately decreased, although

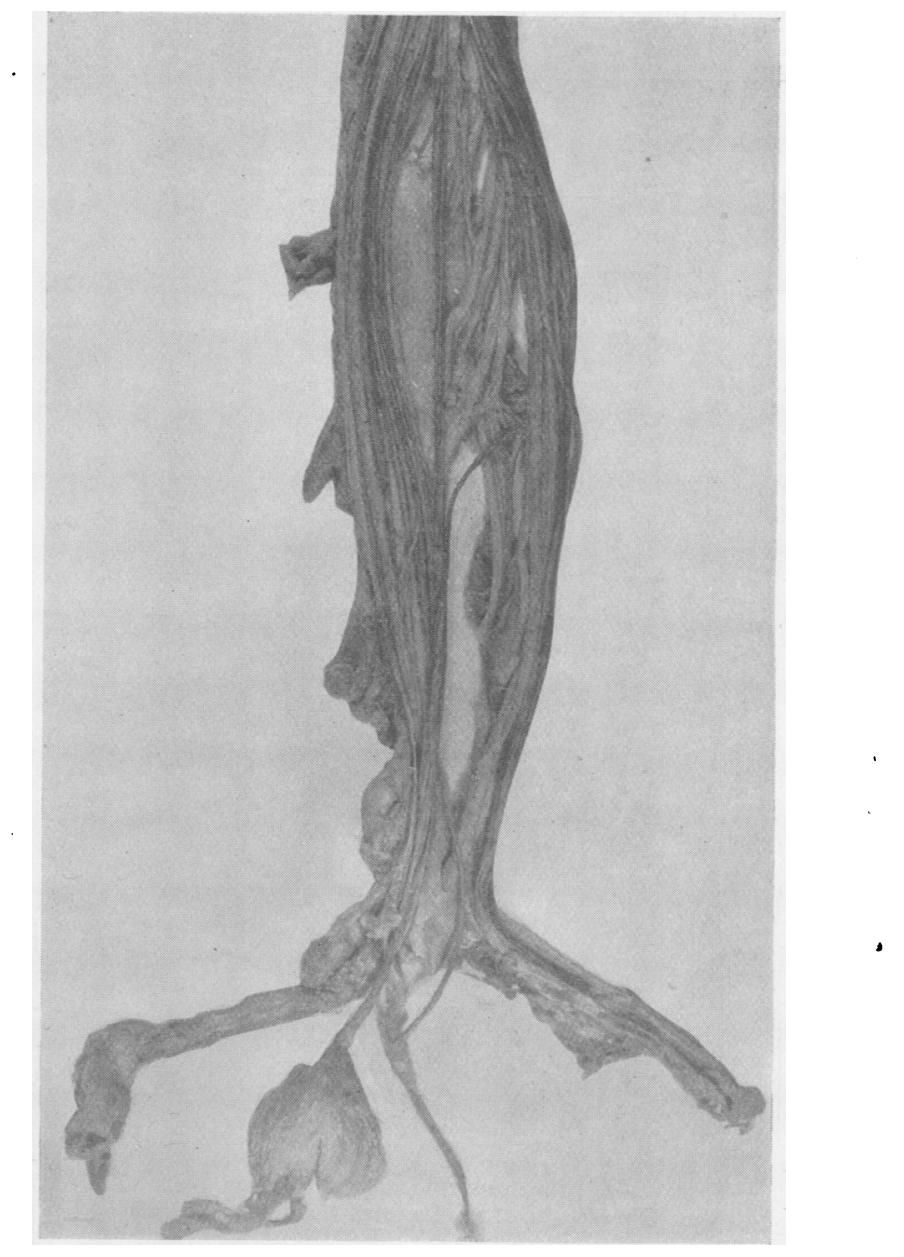

Fig. 1.-Cauda equina showing tumour mass on left fifth sacral root.

the joint sense was normal. There was a definite diminution of response to pain, heat and cold on both legs below the knees, but no impairment of sensation in the saddle area. The Lasègue sign was present bilaterally. The urological consultant stated that the prostatic bed was normal, and a cystoscopy revealed a basal cystitis, which it was thought explained the patient's leucocytosis.

Laboratory Examination.- The blood showed a white blood count of 21,400. The reds numbered 4,620,000, and the hæmoglobin was 87 per cent. Differential count: 
87 per cent. polymorphonuclears. Urine : $30 \mathrm{mg}$. of albumen and 508 white cells per high power field. B. proteus was reported in urine cultures. Gastric analysis : free acid 41, combined 21-total 62 . Blood chemistry : urea 14.4, non-protein nitrogen 34.9, sugar 120.

$X$-rays of the chest showed a circumscribed area in the left upper lobe with striations into the surrounding parenchyma. This was interpreted as a possible metastasis. X-rays of the lumbar spine and sacrum revealed a moderate hypertrophic arthritis. Lumbar puncture on January 1, 1932, showed a partial subarachnoid block.

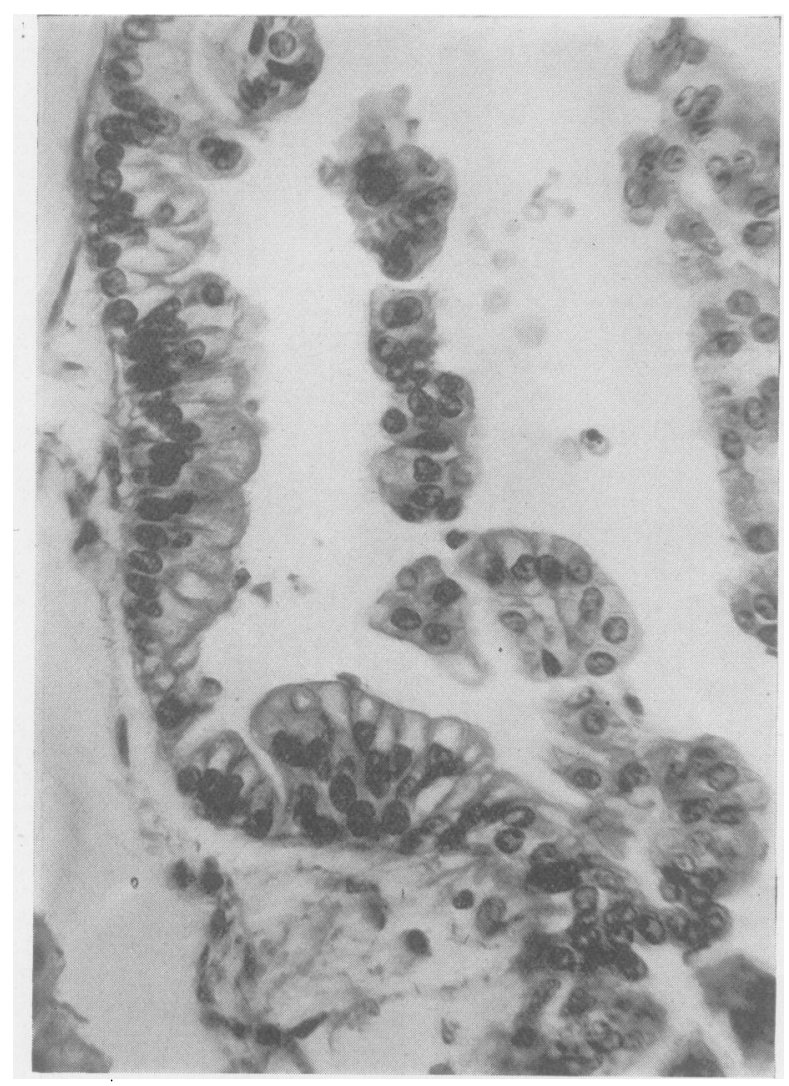

FIG. 2.-Tumour in pia-arachnoid covering pons. Paraffin material. Van Gieson stain. Leitz obj. $4 \mathrm{~mm}$. ; ocular $10 \times$.

The initial pressure was $250 \mathrm{~mm}$. The fluid was slightly xanthochromic and contained seven cells per c.mm. Globulin 3 plus; Wassermann negative and Lange negative. A second puncture on January 4 gave the same findings except that the pressure was $350 \mathrm{~mm}$. and there were only two cells.

Course.-On admission, the patient was mentally confused and could not be certain about the date. His mental state rapidly became worse and his refusal of food and fluids made proctoclysis necessary. On the fourth day he developed an incontinence. On the eighth day his temperature rose to $101^{\circ} \mathrm{F}$. Definite signs of bronchopneumonia were detected. On the morning of the ninth day he died. 
Clinical Diagnosis.-Before autopsy the clinical diagnosis was tumour of the cauda equina, perhaps metastatic.

Necropsy.-This was performed by Dr. Graham Kernwein on January 11, 1932. The chief findings were a terminal bronchopneumonia, with no evidence of metastatic malignancy in the lung, as had been suggested by the $\mathrm{X}$-ray report, and a small adenoma of the right suprarenal gland. Examination of the cauda equina revealed a tumour mass the size of a large olive, adherent to the left fifth sacral root just inside the dura (fig. 1). On close inspection there was an opaque, whitish thickening of the leptomeninges which was most marked over the lumbar cord and the cerebellum.

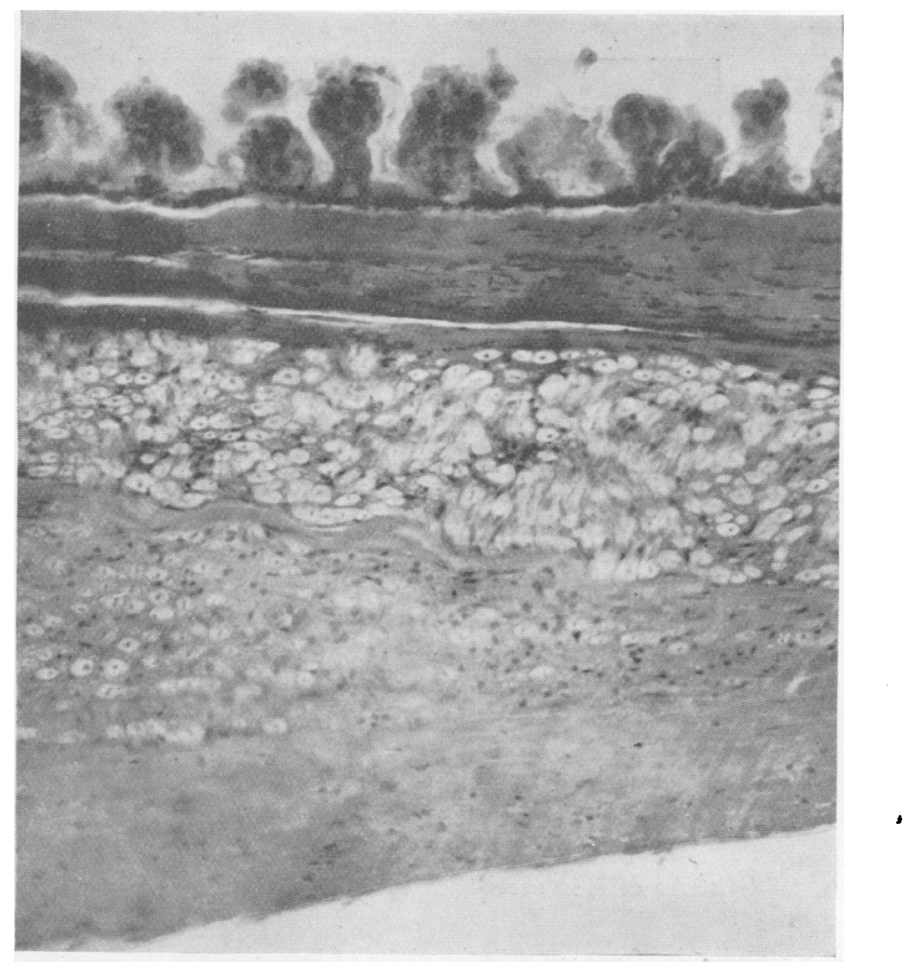

FIs. 3.- Section through wall of cauda tumour showing lining of papilloma cells. Fifth sacral root has been cut across. Hæmatoxylin and eosin.

Gross examination of the brain showed the ventricles to be of normal size and no changes of the choroid plexuses were evident.

Microscopic examination was made and sections stained with Van Gieson's method showed that the structure of the tumour was typical of papilloma choroideum. The cells could be seen to be arranged with the characteristic relations to the core of vessels and connective tissue stroma (fig. 2). Blepharoplasten could not be demonstrated. Sections through the cauda tumour revealed that it was essentially a sac, lined with papilloma cells and filled with coagulated fluid (fig. 3). The tumour cells were found throughout the leptomeninges of the cord and brain, even to the frontal pole, as well as in all the ventricles. In one section it was possible to demonstrate 
groups of tumour cells within the cerebellar cortex (fig. 4). Further examination of the brain and cord gave no evidence of central nervous system syphilis.

\section{COMMENT}

Pathological.-From a pathological standpoint, the chief problem is that gross examination of the choroid plexus of the ventricular system failed to reveal a tumour mass. In many sections, as evident in the illustration from the inferior horn of the lateral ventricle, normal choroid plexus was seen immediately beside the papilloma (fig. 5). Thus it is difficult to decide upon

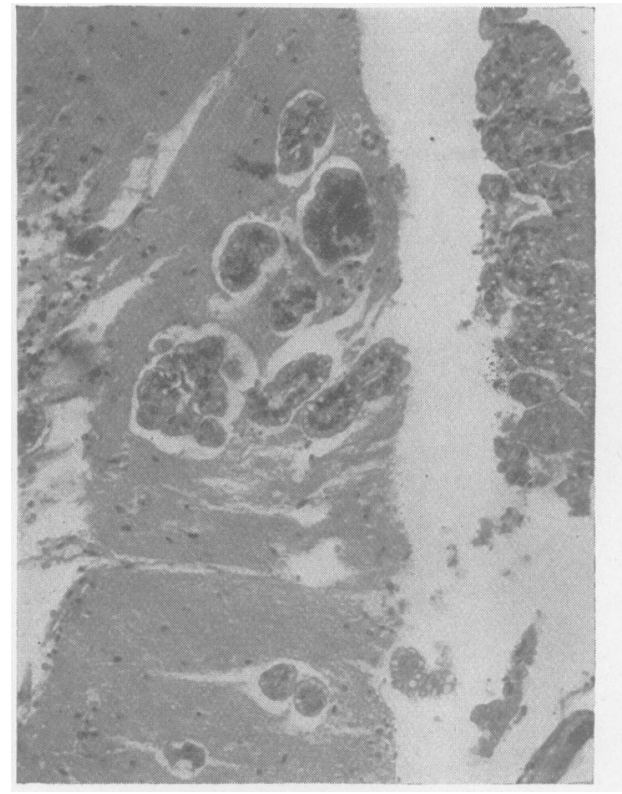

Fig. 4.-Tumour cells in cerebellar cortex. Hæmatoxylin and eosin.

the site of the primary tumour. Probably this question is best solved by the assumption that there was a generalized degeneration of the choroid plexus to form the papilloma. A section from the third ventricle reveals every gradation from normal choroid plexus to typical papilloma cells (fig. 6).

Clinical.-This case presented a most interesting clinical problem. The history of bilateral sciatic pain with bladder disturbance, the diminution of patellar reflexes, the absence of Achilles-jerks and hypæsthesia of the lower extremities, all suggested tumour of the cauda equina. The clinical findings were confirmed by lumbar puncture. However, the loss of $30 \mathrm{lb}$. in weight, and the history of general weakness before the onset of the pains, brought up the question of malignancy with metastasis. The $\mathrm{X}$-ray findings of possible pulmonary metastasis (which, however, were not confirmed at post- 
mortem) tended to corroborate this suspicion. The chief objection to the diagnosis of metastasis was that no clue to the location of the primary tumour could be found. The old luetic history was also a disturbing factor, despite the negative serology.

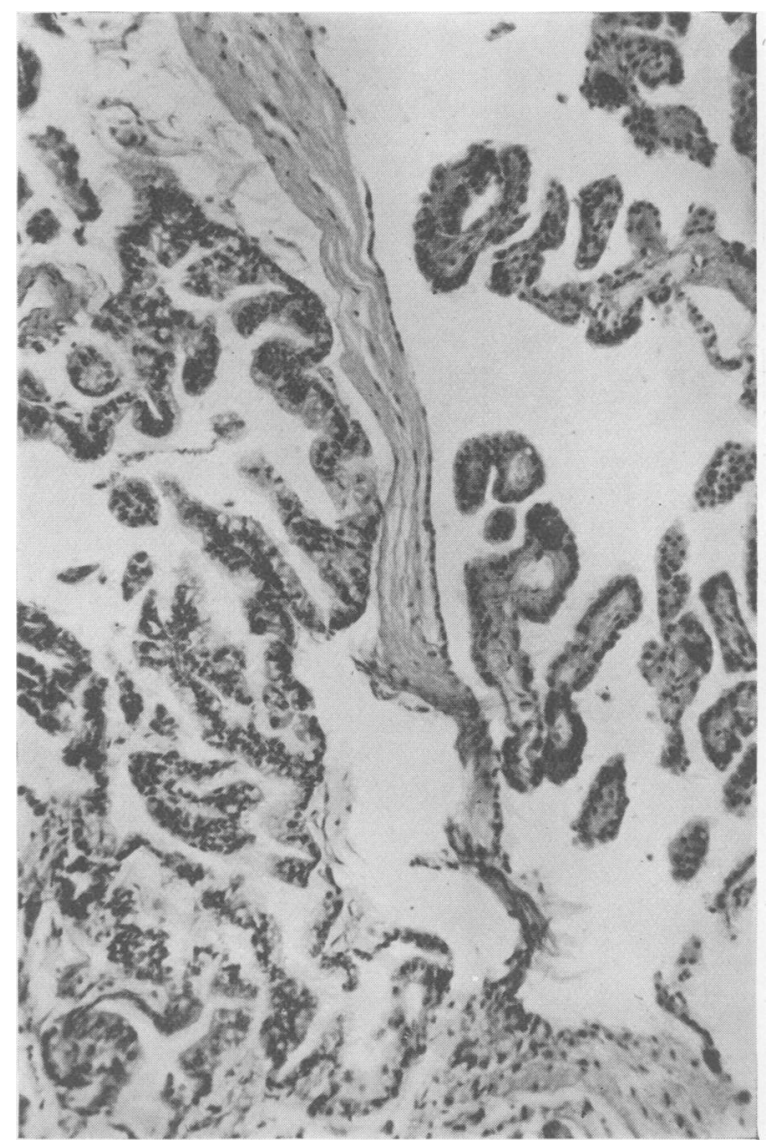

Fig. 5.- Inferior horn of lateral ventricle. Paraffin material. Van Gieson stain. Leitz objective $10 \times$; ocular $10 \times$.

\section{SUMMARY AND GONGLUSIONS}

1. A clinical and pathological report of a case of papilloma choroideum with diffuse central nervous system metastases is presented.

2. The phenomenon of seeding of the meninges by a benign intracranial tumour is demonstrated.

3. The difficulty of clinical diagnosis in such a case is self-evident.

4. One of the chief reasons why the possibility of the primary tumour 
being intracranial was not considered is, that metastasis from these tumours is thought to be rare.

We wish to acknowledge our indebtedness to Dr. J. Kernohan of Rochester, Minnesota, and to Dr. A. Weil of Chicago for their assistance in

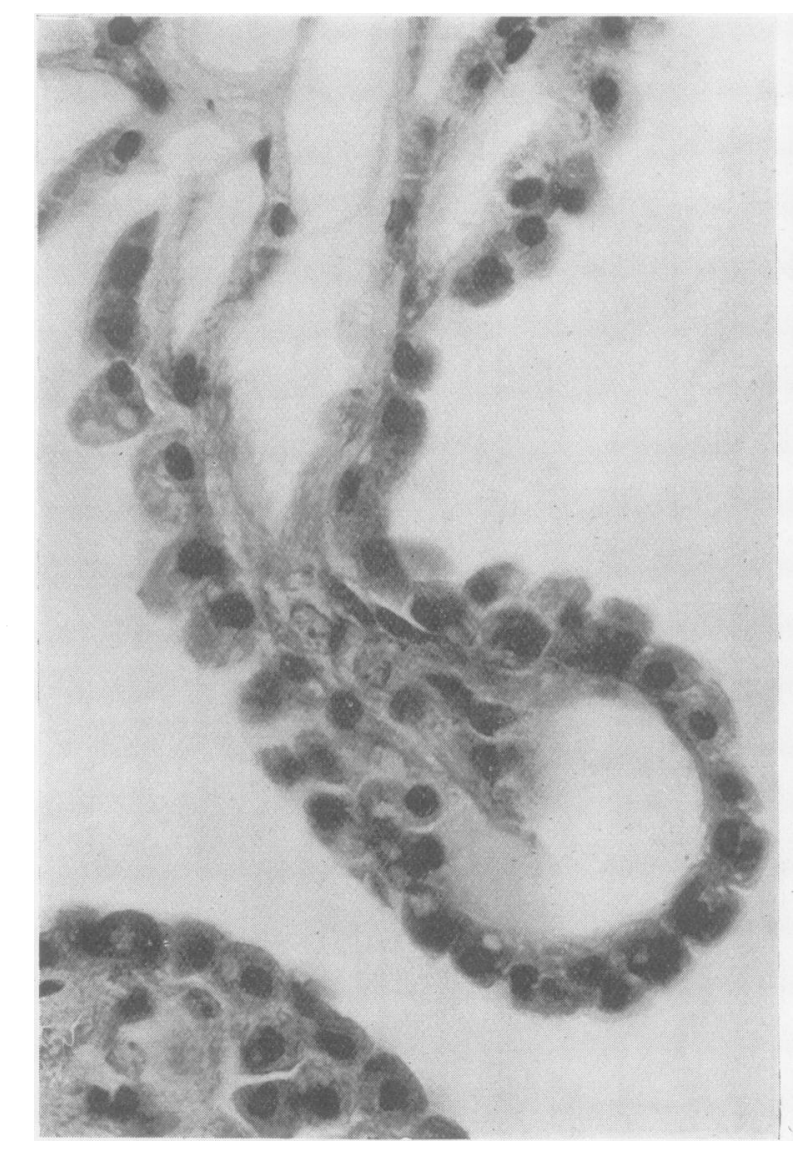

Fig. 6.-Choroid plexus of third ventricle. Paraffin material. Van Gieson stain. Leitz obj. $4 \mathrm{~mm}$.; ocular $10 \times$. Extension $101 \mathrm{~cm}$.

the classification of this tumour, and to Dr. George Funck, who referred the case to us for examination and diagnosis.

\section{REFERENGES}

1 Davis, L. E., and Cushing, H., ' Papillomas of the choroid plexus with a report of six cases,' Arch. Neurol. and Psychiat., 1925, 13, 681.

2 Van Wagenen, William P., 'Papillomas of the choroid plexus,' Arch. of Surg., $1930,20,199$. 
3 Vincent, Cl., et al., ' Papillomes du quatrième ventricule obstruant l'orifice inférieur de l'aqueduc de Sylvius,' Reoue neurol., 1931, 1, 811.

4 Spota, P. B., 'Sindromo de epilepsia jacksoniana extracortical por epitelioma de los plexos coroìdes,' La Semana Médica, 1931, 1, 805.

${ }^{5}$ Guillain, G., et al., 'Papillome des plexus choroïdes du quatrième ventricule simulant une tumeur de l'acoustique,' Revue neurol., 1932, 1, 497.

- Le Blanc, Christian, ' Papillom myxomatodes,' Inaug. Dissert., Bonn, 1868.

7 Bielschowsky, M., and Unger, Ernst, ' Zur Kenntnis der primären Epithelgeschwülste der Adergeflechte des Gehirns,' Arch. f. klin. Chir., 1902, 81, 61.

8 Van BouwdiJk, Bastianse, 'Primäres metastasierender Gehirncarcinom,' Zeits. f. d. g. Neurol. u. Psychiat., 1914, 27, 96.

9 TöppIsch, G., 'Die Zottenkrebse der Adergeflechte der Rautengrube,' Frankfurt. Zeits. f. Path., 1925, 33, 238.

10 Gromelski, Alfred, 'Beitrag zu der Lehre von den primären epithelialen Geschwülsten des zentral Nervensystems,' Virchow's Arch. f. path. Anat., 1926, 261, 933. 